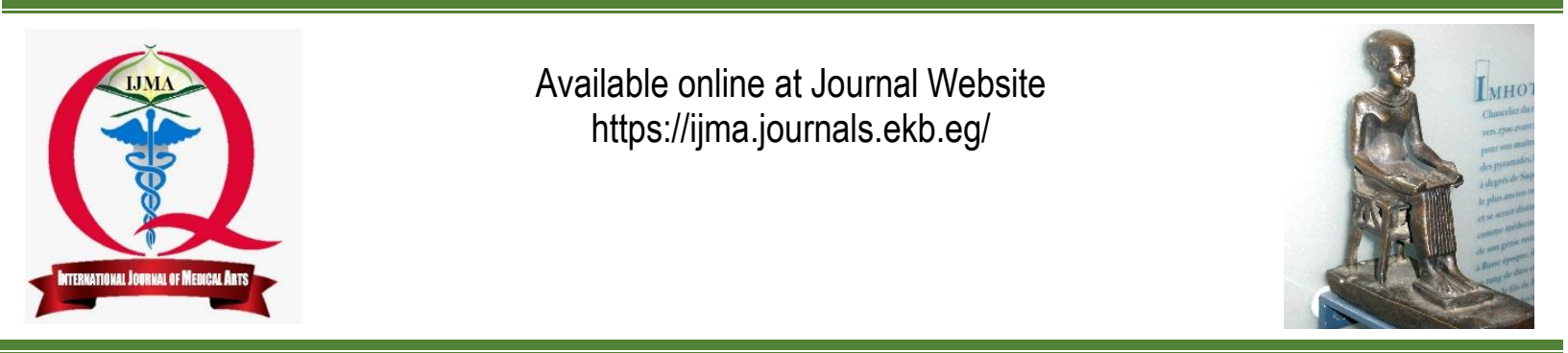

Original article

\title{
Serum Zinc Level in Neonates with Indirect Hyperbilirubinemia
}

\author{
Saeda Reda Alia; Mohamed Abdel-aal ${ }^{\text {b; }}$ Mohamed Elsamanoudy ${ }^{\text {b; }}$ Sabah Ibrahimc
}

Department of Pediatrics, Kafr-Elsheikh General Hospital, Ministry of Health, Egypt [a].

Department of Pediatrics, Damietta Faculty of Medicine, Al-Azhar University, Egypt ${ }^{[b]}$.

Department of Clinical Pathology, Damietta Faculty of Medicine, Al-Azhar University, Egypt[c]

Corresponding author: Saeda Reda Ali

Email: sobhyaliali@gmail.com.

Received at: October 18, 2019; Revised at: December 18, 2019; Accepted at: December 21, 2019; Available online at: December 21, 2019

\section{ABSTRACT}

Background: The most common cause of hospital admission in the first month of life is the neonatal jaundice. Some factors [e.g., prenatal, neonatal factors, maternal factors, and environmental factors (such as zinc) influence the frequency of neonatal jaundice. In terms of neonates, it is proposed that there is a correlation between serum zinc quality and hyperbilirubinemia.

Aim of the work: To evaluate the level of serum zinc in term neonates with indirect hyperbilirubinemia.

Patients and methods: A case control study carried out at the neonatal intensive care unit (NICU) and pediatric outpatient clinic of New Damietta, Al-Azhar University Hospital, from June 2018 to February 2019. It included 75 neonates with neonatal jaundice as cases group and 75 healthy neonates of matched age and sex as a control group. All were assessed clinically and serum zinc levels were determined and documented.

Results: Level of serum zinc in neonates with non-hemolytic hyperbilirubinemia $(103.3 \pm 36.56 \mathrm{ug} / \mathrm{dl})$ was significantly lower than healthy neonates without jaundice (128.62 $\pm 40.83 \mathrm{ug} / \mathrm{dl})$ and zinc deficiency in jaundiced neonates $(25.3 \%)$ was statistically significant more than healthy neonates $(6.7 \%)$. There was no significant relation between the level of serum zinc and other factors like the maternal age, parity, pattern of feeding, gender and weight, but there was significant correlation with maternal zinc intake during pregnancy.

Conclusion: We concluded that serum zinc level in term neonates with neonatal jaundice was statistically significant decreased than healthy term neonates.

Keywords: Zinc; Indirect; Hemolytic; Hyperbilirubinemia; Neonates.

This is an open access article under the Creative Commons license [CC BY] [https://creativecommons.org/licenses/by/2.0/]

Please cite this article as: Ali SR, Abdel-aal M, Elsamanoudy M, Ibrahim S. Serum Zinc Level in Neonates with Indirect Hyperbilirubinemia. IJMA 2020; 2(1): 217-222. 


\section{INTRODUCTION}

Neonatal jaundice is defined as yellow discoloration of the sclera, skin and mucous membranes caused by tissue deposition of bilirubin. When the total serum bilirubin level (TSB) is 5 $\mathrm{mg} / \mathrm{dL}$, it becomes apparent. ${ }^{[1]}$ Neonatal jaundice is considered one of the most common conditions requiring medical attention in neonates; in the first week of life, approximately $80 \%$ of preterm neonates and $60 \%$ of term neonates experience jaundice. ${ }^{[2]}$ Treatment in neonates for unconjugated hyperbilirubinemia, such as phototherapy and blood exchange transfusion, is costly, takes a long time and can be dangerous. Certain therapies to avoid bilirubin neurotoxicity by reducing the level of unconjugated bilirubin by enterohepatic circulation inhibition are available. ${ }^{[3]}$

Zinc is one of the critical trace elements for normal function and is therefore associated with tragic deficiencies when deficient. ${ }^{[4]}$

Zinc plays a vital role in a wide range of biological activities, including nucleic acid metabolism, immune function by serving as a cofactor in the development of more than 200 enzymes, e.g. metalloproteinases, phosphatases, oxide-reducatases, protein synthesis and cell function preservation. ${ }^{[5]}$

For intestinal bilirubin binding, several materials have been used to avoid its absorption; for example, the use of laxatives and oral agar. It has also been shown that oral zinc salts at normal body $\mathrm{pH}$ reduce the maximum bilirubin serum since they deposit unconjugated bilirubin. ${ }^{[6]}$

Inhibition of enterohepatic circulation is one important approach to preventing neonatal hyperbilirubinemia. Zinc has been reported to decrease bilirubin levels by inhibition of enterohepatic circulation. [7]

Zinc sulfate supplementation has been reported to have some potential to decrease total serum bilirubin (TSB), hyperbilirubinemia, and phototherapy time. ${ }^{[8]}$

\section{AIM OF THE STUDY}

Evaluation of serum zinc level in term neonates with indirect hyperbilirubinemia was the objective of this study.

\section{PATIENTS AND METHODS}

A case control study was carried out at the neonatal intensive care unit (NICU) and outpatient clinic of Al-Azhar university hospital (New Damietta), starting from June 2018 to February 2019. The study included 150 term neonates who were randomly selected, and fulfilled the inclusion criteria; 75 neonates with non-hemolytic neonatal jaundice as a study group and 75 healthy controls of matched age and sex.

Inclusion criteria included full-term neonates, of both genders, age 2-10 days and weight $\geq$ $2500 \mathrm{~g}$.

We excluded all infants with major congenital malformations, presence of any systemic illness (sepsis, infant of diabetic mother, hypoxic ischemic encephalopathy and respiratory distress), chronic disease of the mother and neonates with $\mathrm{ABO}$ incompatibility, Rh incompatibility and cephalhematoma. During this study we excluded 8 infants with $A B O$ and $R h$ incompatibility, 3 neonates with sepsis, 2 infants with cephalhematoma and 3 cases due to failure of sampling.

We explained to the guardians the purpose of the study and an informed consent was given by each guardian. Furthermore, confidentiality of all data was guaranteed. All newborns in the sample are subjected to complete history, detailed medical review, laboratory investigations (complete blood count $(C B C)$, total serum bilirubin (TSB), Direct serum bilirubin (DSB), blood grouping, reticulocyte count and serum zinc level by commercially available spectrophotometric kits). The normal reference value was $80-120 \mu \mathrm{g} / \mathrm{dl}$ according to test scope. [9] Low zinc deficiency recognized at serum levels of 60-79 $\mathrm{gg} / \mathrm{dl}$, moderate zinc deficiency if levels $<59 \mu \mathrm{g} / \mathrm{dl}$ and extreme zinc deficiency if levels $<30 \mu \mathrm{g} / \mathrm{dl}$. [10]

Statistical analysis: The statistical Package for social sciences, version 20.0 (IBM, SPSS Inc., Chicago, Illinois, USA) was used to coordinate, record and analyze data. For quantitative variables, mean and standard deviation (SD) were estimated, while for qualitative variables frequency and percentages were calculated. The student (t) was used to compare two concepts, while the Chisquare $\left(x^{2}\right)$ was used to compare the ratios of two qualitative variables. The confidence interval was 
$95 \%$ and the accepted error margin was set at $5 \%$. If $(P$-value $<0.05)$ the $p$-value was considered significant.

\section{RESULTS}

This study was conducted on 75 full-term neonates with neonatal jaundice; they were 42 males (56\%) and 33 females (44\%). In addition, 75 healthy control group of matched age and gender were included as well, males represented 39 $(52.0 \%)$ and females were $36(48.0 \%)$ of this group. Mean age of cases was $5.93 \pm 1.89$ days. Multiparity accounted for $58.7 \%$ of cases and cesarean section (CS) accounted for $76.0 \%$ of cases, and there was no significant difference regarding all demographic data between both cases and control groups (Table 1).

Zinc deficiency was more frequent among cases $(25.3 \%)$ than control group $(6.7 \%)$ and this difference was statistically significant with ( $p$. value $=0.002$ ). In addition, mean serum zinc level was significantly $(p=0.001)$ decreased in cases (103.33 $\mu \mathrm{g} / \mathrm{dl})$ than control group $(128.62 \mu \mathrm{g} / \mathrm{dl})$ (Table 2).
There was no significant difference between deficient zinc in cases and control group regarding sex, gestational age (GA), feeding, maternal age, previous sibling with jaundice and $100 \%$ of mothers in both subgroups had no history of zinc supplementation. But, there was a statistically significant difference between cases and control regarding serum zinc level (Table3).

There was negative correlation between serum zinc with weight and TSB and positive correlation with other parameters (GA, age, onset of jaundice, maternal age and DSB); however, this correlation was statically non-significant (Table 4).

The mean serum zinc was $99.20 \pm 31.40 \mathrm{ug} / \mathrm{dl}$ with multiparity and it was $88.90 \pm 24.60 \mathrm{ug} / \mathrm{dl}$ in cases with previous sibling with jaundice and was higher with bottle feeding $120.10 \pm 54.90 \mathrm{ug} / \mathrm{dl}$ than breast feeding and it was $144.00 \pm 59.90 \mu \mathrm{g} / \mathrm{dl}$ with maternal zinc intake, however; there was no significance except with maternal zinc intake (Table $5)$.

Table [1]: Difference between cases and control group regarding demographic data

\begin{tabular}{|c|c|c|c|c|}
\hline \multirow{2}{*}{ Variables } & \multirow{2}{*}{$\begin{array}{l}\text { Cases group } \\
\quad(\mathrm{N}=75)\end{array}$} & \multirow{2}{*}{$\begin{array}{l}\text { Control group } \\
\qquad(\mathrm{N}=75)\end{array}$} & \multicolumn{2}{|c|}{$\begin{array}{c}\text { Chi square } \\
\text { testllndependent } t \text { test }\end{array}$} \\
\hline & & & $\mathrm{X}^{2} / \mathrm{t}^{\star}$ & $P$ value \\
\hline $\begin{array}{cc}\text { Sex }(\%) & \text { Males } \\
& \text { Females } \\
\end{array}$ & $\begin{array}{l}42(56.0 \%) \\
33(44.0 \%)\end{array}$ & $\begin{array}{l}39(52.0 \%) \\
36(48.0 \%)\end{array}$ & 0.242 & 0.623 \\
\hline Gestational age (week) (mean \pm SD) & $38.15 \pm 1.19$ & $38.13 \pm 1.11$ & $0.071^{*}$ & 0.944 \\
\hline Age (days) (mean \pm SD) & $5.93 \pm 1.89$ & $6.37 \pm 1.75$ & $1.480^{*}$ & 0.141 \\
\hline Maternal age (years) (mean $\pm S D)$ & $25.25 \pm 4.51$ & $24.91 \pm 4.31$ & $0.481^{*}$ & 0.631 \\
\hline $\begin{array}{ll}\text { Multiparity (\%) } & \text { No } \\
& \text { Yes }\end{array}$ & $\begin{array}{l}31(41.3 \%) \\
44(58.7 \%)\end{array}$ & $\begin{array}{l}35(46.7 \%) \\
40(53.3 \%)\end{array}$ & 0.433 & 0.511 \\
\hline $\begin{array}{r}\text { Mode of labor (\%) CS } \\
\text { Vaginal } \\
\end{array}$ & $\begin{array}{l}57(76.0 \%) \\
18(24.0 \%) \\
\end{array}$ & $\begin{array}{l}52(69.3 \%) \\
23(30.7 \%) \\
\end{array}$ & 0.839 & 0.360 \\
\hline
\end{tabular}

Table [2]: Difference between cases group \& control group regarding serum zinc level $(\mu \mathrm{g} / \mathrm{dl})$

\begin{tabular}{|c|c|c|c|c|c|}
\hline \multirow{2}{*}{\multicolumn{2}{|c|}{ Variables }} & \multirow{2}{*}{$\begin{array}{l}\text { Cases } \\
\text { group } \\
(\mathrm{N}=75)\end{array}$} & \multirow{2}{*}{$\begin{array}{l}\text { Control group } \\
\qquad(\mathrm{N}=75)\end{array}$} & \multicolumn{2}{|c|}{$\begin{array}{c}\text { Chi square testl } \\
\text { Independent t test }\end{array}$} \\
\hline & & & & $X^{2} / t^{*}$ & $P$ value \\
\hline Serum zinc $(\mu \mathrm{g} / \mathrm{dl})$ & $\begin{array}{l}\text { Deficient } \\
\text { Normal }\end{array}$ & $\begin{array}{l}19(25.3 \%) \\
56(74.7 \%)\end{array}$ & $\begin{array}{c}5(6.7 \%) \\
70(93.3 \%) \\
\end{array}$ & 9.722 & 0.002 \\
\hline \multicolumn{2}{|c|}{ Serum zinc level (ug/dl)(mean \pm SD) } & $103.33 \pm 36.56$ & $128.62 \pm 40.83$ & $3.996^{*}$ & 0.001 \\
\hline
\end{tabular}


Ali SA, et al.

Table (3): Comparison between deficient zinc in cases group and deficient zinc in control group as regards serum zinc and demographic data

\begin{tabular}{|c|c|c|c|c|}
\hline \multirow[t]{2}{*}{ Variables } & \multirow{2}{*}{$\begin{array}{l}\text { Deficient zinc } \\
\text { in cases } \\
(n=19)\end{array}$} & \multirow{2}{*}{$\begin{array}{l}\text { Deficient zinc } \\
\text { in control } \\
(n=5)\end{array}$} & \multicolumn{2}{|c|}{$\begin{array}{c}\text { Chi square } \\
\text { testllndependent } t \text { test }\end{array}$} \\
\hline & & & $X^{2} / t^{*}$ & $P$ value \\
\hline $\begin{array}{l}\text { Males } \\
\text { Females }\end{array}$ & $\begin{array}{c}8(42.1 \%) \\
11(57.9 \%)\end{array}$ & $\begin{array}{l}2(40.0 \%) \\
3(60.0 \%)\end{array}$ & 0.007 & 0.932 \\
\hline $\begin{array}{ll}\text { Maternal zinc intake } & \text { No } \\
& \text { Yes }\end{array}$ & $\begin{array}{c}19(100.0 \%) \\
0(0.0 \%)\end{array}$ & $\begin{array}{c}5(100.0 \%) \\
0(0.0 \%)\end{array}$ & NA & NA \\
\hline $\begin{array}{l}\text { Breast } \\
\text { Bottle } \\
\text { Mixed }\end{array}$ & $\begin{array}{l}11(57.9 \%) \\
2(10.5 \%) \\
6(31.6 \%)\end{array}$ & $\begin{array}{l}4(80 \%) \\
0(0.0 \%) \\
1(20 \%)\end{array}$ & 1.018 & 0.601 \\
\hline Maternal age (years)(mean \pm SD) & $24.05 \pm 3.29$ & $25.66 \pm 4.81$ & 1.350 & 0.181 \\
\hline $\begin{array}{r}\text { Previous sibling of jaundice (\%): } \\
\text { No } \\
\text { Yes }\end{array}$ & $\begin{array}{l}15(78.9 \%) \\
4(21.1 \%)\end{array}$ & $\begin{array}{l}4(80.0 \%) \\
1(20.0 \%)\end{array}$ & 0.003 & 0.959 \\
\hline Serum zinc level $(\mu \mathrm{g} / \mathrm{dl})($ mean $\pm S D)$ & $67.67 \pm 5.74$ & $74 \pm 3.16$ & -2.347 & 0.028 \\
\hline Gestational age (week) (mean \pm SD) & $37.95 \pm 1.08$ & $37.80 \pm 0.45$ & 0.295 & 0.771 \\
\hline
\end{tabular}

Table (4): Correlation between serum zinc level as other parameters in cases group

\begin{tabular}{|l|c|c|}
\hline \multirow{2}{*}{ Variables } & $\mathbf{c}$ Serum zinc $(\boldsymbol{\mu g} / \mathbf{d} \mathbf{d})$ \\
\cline { 2 - 3 } & $\mathbf{r}$ & $\mathbf{P}$ value \\
\hline GA (week) & 0.146 & 0.211 \\
\hline Age(days) & 0.126 & 0.282 \\
\hline Onset of jaundice (days) & 0.090 & 0.442 \\
\hline Maternal age (years) & 0.084 & 0.471 \\
\hline Weight (kg) & -0.034 & 0.775 \\
\hline TSB (mg/dl) & -0.075 & 0.520 \\
\hline DSB (mg/dl) & 0.052 & 0.655 \\
\hline GA: Gestational age; DSB: Direct serum bilirubin; TSB: Total serum bilirubin. \\
\hline
\end{tabular}

Table (5): Relation between serum zinc level as regard other parameters in cases group

\begin{tabular}{|c|c|c|c|}
\hline \multirow[t]{2}{*}{ Variables } & \multirow[t]{2}{*}{ Serum zinc (ug/dl) } & \multicolumn{2}{|c|}{$\begin{array}{l}\text { Independent } t \text { test/ } \\
\text { One-way ANOVA }\end{array}$} \\
\hline & & $t / f^{*}$ & $P$ value \\
\hline $\begin{array}{ll}\text { Multi parity } & \text { No } \\
& \text { Yes }\end{array}$ & $\begin{array}{c}109.20 \pm 42.70 \\
99.20 \pm 31.40\end{array}$ & 1.117 & 0.243 \\
\hline $\begin{array}{r}\text { Maternal zinc intake } \\
\text { No } \\
\text { Yes }\end{array}$ & $\begin{array}{c}101.60 \pm 34.90 \\
144.00 \pm 59.90\end{array}$ & 2.006 & 0.049 \\
\hline $\begin{array}{l}\text { Breast } \\
\text { Bottle } \\
\text { Mixed }\end{array}$ & $\begin{array}{l}103.60 \pm 34.20 \\
120.10 \pm 54.90 \\
95.90 \pm 32.80\end{array}$ & 1.275 & 0.286 \\
\hline $\begin{array}{c}\text { Previous sibling with jaundice (\%) } \\
\text { No } \\
\text { Yes }\end{array}$ & $\begin{array}{c}105.80 \pm 37.80 \\
88.90 \pm 24.60\end{array}$ & 1.424 & 0.159 \\
\hline
\end{tabular}




\section{DISCUSSION}

This research was designed to assess the amount of serum zinc in neonates with indirect hyperbilirubinemia. Zinc $(Z n)$ is considered a critical trace element with a range of biological effects depending on its structural and catalytic role in a large number of enzymes and "Zn-finger" proteins. Serum zinc deficiency can result in the development of deficient enzymes that act in the metabolism of bilirubin [11]. Zinc salts will potentially inhibit bilirubin and its enterohepatic circulation by precipitating unconjugated bilirubin in the intestine. [12]

Zinc may result in deficient synthesis of various enzymes that play a role in the metabolism of bilirubin, in particular the $Z$ and $Y$ proteins, resulting in neonatal jaundice. [13]

With respect to demographic data of studied groups, the percentage of males was 56 percent higher than 44 percent of females, the male to female ratio in cases was 1.2:1. This in agreement with Boskabadi et al. ${ }^{[3]}$ who reported that male to female ratio was (1.2:1) and Hasan ${ }^{[4]}$ who reported that male to female ratio was (1.3:1) with male predominance. In fact, male newborns are always more susceptible to neonatal jaundice, although the cause remains unknown.[14]

The control mean age was $6.37 \pm 1.75$ days that was comparable to the study of Boskabadi et al. [3] who showed that the mean age $6.75 \pm 4.88$ days in the control group. In addition, the mean gestational age in cases was $38.15 \pm 1.19$ week and in control group was $38.13 \pm 1.11$ week that was comparable to the study of Tan et al. [15] who reported GA of $38.48 \pm 1.15$ week in cases and $38.15 \pm 1.03$ week in control group.

The difference of gender, gestational age and age between cases and controls were statistically nonsignificant. This was in agreement with AlHajjiahNasmaa ${ }^{[16]}$, Boskabadi et al. ${ }^{[3]}$ and Tan et al. [15].

Majority of cases (76\%) were delivered by caesarian section, which is more frequent in cases than control group and this was in agreement with the study of Tavakolizadeh et al.[17].

In the current work, serum Zn was significantly reduced in cases when compared to control group. This is in agreement with Boskabadi et al..[3] and Al-HajjiahNasma[16] who reported statistically significant relation between neonatal jaundice and zinc deficiency. In addition, Hasan [4] and Tan et al. ${ }^{[15]}$ revealed similar results.

The prevalence of zinc deficiency in cases group was $25.3 \%$ and $6.7 \%$ in control group. This agree with Al-HajjiahNasma [16].

As in the present work, Al-HajjiahNasma[16] showed no significant association between neonatal jaundice and gestational age or parity $(P>$ 0.05). Also, Boskabadi et al. [3] showed similar results. The same authors reported that there was no statistically significant association between level serum zinc and each of weight, sex, serum bilirubin, and maternal age which is consistent with the current study.

We found significant correlation between level of serum zinc of cases and maternal zinc intake during pregnancy which agrees with Al-HajjiahNasma [16].

In the current study, breast feeding was more frequent in both deficient zinc in cases $(57.9 \%)$ and deficient zinc in control $(80 \%)$, with significantly lower serum zinc levels among breast-fed when compared to formula fed neonates. This agrees with Ali et al. [18]. This could be explained by zinc deficiency and absence of zinc supplementation among mothers.

In conclusion, zinc deficiency in jaundiced cases $(25.3 \%)$ is more frequent than healthy neonates $(6.7 \%)$ and serum zinc levels are significantly lower in term neonates with hyperbilirubinemia than stable neonates without jaundice. Thus, zinc supplementation is recommended for pregnant mothers.

\section{Financial and Conflict of interest disclosure}

None

\section{REFERENCES}

1- Pan DH, Rivas Y. Jaundice: Newborn to age 2 months. Pediatr Rev. 2017 Nov;38(11):499-510. [DOI: 10.1542/pir.2015-0132]

2- Amos RC, Jacob H, Leith W. Jaundice in newborn babies under 28 days: NICE guideline 2016. Arch 
Dis Child Educ Pract Ed. 2017; 102 (4): 207-209. [DOI:10.1136/archdischild-2016- 311556].

3- Boskabadi H, Maamouri G, Zadeh HM, Shakeri MT, Ghayour-Mobarhan M, Mohammadi S, Ferns G. Comparison of Serum Zinc Level Between Neonates with Jaundice and Healthy Neonates. Shiraz E-Med J. 2015; 16(10): e27392. [Doi: 10.17795/semj 27392].

4-Hasan EJ. Evaluation of Copper, Zinc, Manganese, and Magnesium Levels in Newborn Jaundice in Baghdad. Ibn AL-Haitham J Pure Appl Sci 2017; 24(3).

5-Jyotsna S, Amit A, Kumar A. Study of serum zinc in low birth weight neonates and its relation with maternal zinc. J Clin Diagn Res. 2015 Jan;9(1):SC01-3. [DOI:10.7860/JCDR/2015/ 10449. 5402].

6- Beiranvand S, Hosseinabadi R, Firouzi M, Almasian M, Anbari K. Impact of Combined Oral Zinc Sulfate and Phototherapy on Serum Bilirubin Levels in the Term Neonates with Jaundice. Iran J Neonatol. 2018;9(3):20-5. [DOI: 10.22038/ ijn. 2018. 27173.1361].

7- Yang L, Wu D, Wang B, Bu X, Tang J. The influence of zinc sulfate on neonatal jaundice: a systematic review and meta-analysis. The $\mathrm{J}$ Matern Fetal Neonatal Med. 2018; 31 (10): 1311-1317. [DOI: 10.1080/14767058.2017. 1315659].

8- Kumar A, Bagri NK, Basu S, Asthana RK. Zinc supplementation for neonatal hyper-bilirubinemia: a randomized controlled trial. Indian pediatr 2014; 51:375-378. [ DOI: 10.1007/s13312-014-0420-1].

9- Shenken A, Roberts NB. Vitamins and trace elements. In: Burtis C A \& Bruns D E editors. Tietz textbook of clinical chemistry and molecular diagnostics-e-book. Elsevier Health Sciences. $7^{\text {th }}$ ed., (2015), pp 494- 497.

10- Yanagisawa $\mathrm{H}$. Zinc deficiency and clinical practice. Japan Med Ass J 2004; 47(8): 359-364.

11- El-Mazary AA, Abdel Aziz R, Sayed M, Mahmoud R, Saedii A. Effect of Intensive Phototherapy and Exchange Transfusion on Copper, Zinc and Magnesium Serum Levels in Neonates with Indirect Hyperbilirubinemia. Int J Pediatr 2017; 5 (2): 43714383. [DOI: 10.22038/ ijp.2017.20566.1716].
12- Mosayebi Z, Rahmani M, Ardakani SB, Sheikh M, Shariat M, Rezaeizadeh G. Evaluation of serum zinc levels in hyper-bilirubinemic neonates before and after phototherapy. Iran J Pediatr. 2016; 26(3): e4146. [Doi: 10.5812/ijp.4146].

13- Abdel Aziz RA, El-Mazary AM, Saidii AA. Can Exchange Transfusion Normalize Serum Levels of Copper, Zinc, and Magnesium in Severe Neonatal Hyperbilirubinemia? J Pediatr Hematol Oncol. 2018;40(2): e121-e126. [DOI: 10.1097/MPH. 0000000000000 875].

14- Garosi E, Mohammadi F, Ranjkesh F. The relationship between neonatal jaundice and maternal and neonatal factors. Iranian J Neonatol 2016; 7(1), 37-40. [DOI: 10.22038/ ijn.2016.6663].

15- Tan H, Karakelleoğlu C, Akçay F, Akdağ R \& Alp H. Serum concentrations of zinc, magnesium, manganese and copper in neonatal jaundice. Atatürk Üniversitesi Tıp Dergisi; Cilt: 32/Sayı:(1) (2000); 912. [English Abstract].

16- Al-HajjiahNasma N. The Study of the effect of serum zinc level in the mothers and Neonates on neonatal jaundice in al-diwanyia. Al-Qadisiyah Med J 2018; 14.25: 88-102.

17-Tavakolizadeh R, Izadi A, Seirafi G, Khedmat L, Mojtahedi SY. Maternal risk factors for neonatal jaundice: a hospital-based cross-sectional study in Tehran. Eur J Transl Myol. 2018; 28(3): 7618. [Doi: 10.4081/ ejtm. 2018.7618].

18- Ali Z, Khan Al, Umar S. Frequency of Zinc Deficiency in Exclusively breast-fed infants presenting in a Tertiary Care Hospital. PJMHS 2016; 10 (3): 851-854. 